\title{
cAMP, Ca 2+, pHi, and NO Regulate H-like Cation Channels That Underlie Feeding and Locomotion in the Predatory Sea Slug Pleurobranchaea californica
}

DOI:

10.1021/acschemneuro.8b00187

\section{Document Version}

Accepted author manuscript

Link to publication record in Manchester Research Explorer

Citation for published version (APA):

Green, D. J., Huang, R., Sudlow, L., Hatcher, N., Potgieter, K., Mccrohan, C., Lee, C., Romanova, E. V., Sweedler, J. V., Gillette, M. L. U., \& Gillette, R. (2018). cAMP, Ca 2+, pHi, and NO Regulate H-like Cation Channels That Underlie Feeding and Locomotion in the Predatory Sea Slug Pleurobranchaea californica. ACS Chemical Neuroscience, 9(8), 1986-1993. https://doi.org/10.1021/acschemneuro.8b00187

\section{Published in:}

ACS Chemical Neuroscience

\section{Citing this paper}

Please note that where the full-text provided on Manchester Research Explorer is the Author Accepted Manuscript or Proof version this may differ from the final Published version. If citing, it is advised that you check and use the publisher's definitive version.

\section{General rights}

Copyright and moral rights for the publications made accessible in the Research Explorer are retained by the authors and/or other copyright owners and it is a condition of accessing publications that users recognise and abide by the legal requirements associated with these rights.

\section{Takedown policy}

If you believe that this document breaches copyright please refer to the University of Manchester's Takedown Procedures [http://man.ac.uk/04Y6Bo] or contact uml.scholarlycommunications@manchester.ac.uk providing relevant details, so we can investigate your claim.

\section{OPEN ACCESS}




\title{
CAMP, $\mathrm{Ca}^{2+}, \mathrm{pH}_{\mathrm{i}}$, and NO Regulate $\mathrm{H}$-like Cation Channels That Underlie Feeding and Locomotion in the Predatory Sea Slug Pleurobranchaea californica
}

\author{
Daniel J. Green, ${ }^{\dagger, \#}$ Rong-Chi Huang, ${ }^{\ddagger}, \nabla$ Leland Sudlow, ${ }^{\ddagger} \bigcirc$ Nathan Hatcher, ${ }^{\ddagger} \diamond$ Kurt Potgieter, ${ }^{\ddagger}, \mathbb{I}$
} Catherine McCrohan, ${ }^{\S}$ Colin Lee, ${ }^{\dagger}$ Elena V. Romanova, ${ }^{\circledR \odot}$ Jonathan V. Sweedler, ${ }^{\circ}$

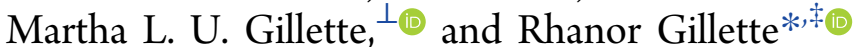

${ }^{\dagger}$ Neuroscience Program, University of Illinois at Urbana-Champaign, Urbana, Illinois 61801, United States
${ }^{\ddagger}$ Department of Molecular \& Integrative Physiology, University of Illinois at Urbana-Champaign, Urbana, Illinois 61801, United
States
${ }^{\S}$ School of Biological Sciences, University of Manchester, Manchester M13 9PT, United Kingdom
${ }^{\|}$Beckman Institute for Advanced Science and Technology and Department of Chemistry, University of Illinois at
Urbana-Champaign, Urbana, Illinois 61801, United States
${ }^{\perp}$ Department of Cell \& Developmental Biology, University of Illinois at Urbana-Champaign, Urbana, Illinois 61801, United States

Supporting Information

\begin{abstract}
A systems approach to regulation of neuronal excitation in the mollusc Pleurobranchaea has described novel interactions of cyclic AMP-gated cation current $\left(\mathrm{I}_{\mathrm{Na}, \mathrm{cAMP}}\right)$, $\mathrm{Ca}^{2+}, \mathrm{pH}_{\mathrm{i}}$, and NO. $\mathrm{I}_{\mathrm{Na}, \mathrm{AMMP}}$ appears in many neurons of feeding and locomotor neuronal networks. It is likely one of the family of hyperpolarization-activated, cyclic-nucleotidegated currents (h-current) of vertebrate and invertebrate pacemaker networks. There are two isoforms. $\mathrm{Ca}^{2+}$ regulates both voltage dependence and depolarization-sensitive in-

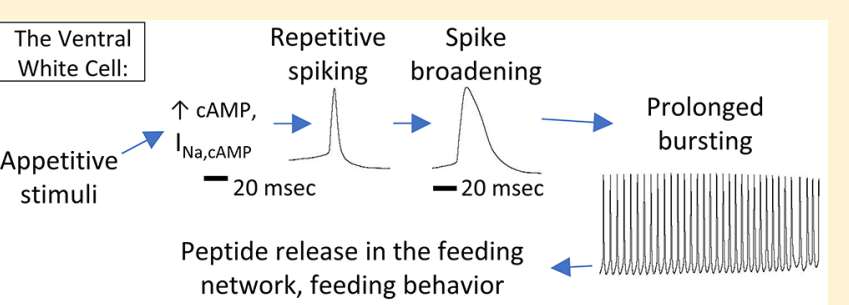
network, feeding behavior activation in both isoforms. The Type $1 \mathrm{I}_{\mathrm{Na}, \mathrm{cAMP}}$ of the feeding network is enhanced by intracellular acidification. A direct dependence of $\mathrm{I}_{\mathrm{Na}, \mathrm{cAMP}}$ on cAMP allows the current to be used as a reporter on cAMP concentrations in the cell, and from there to the intrinsic activities of the synthetic adenyl cyclase and the degradative phosphodiesterase. Type $2 \mathrm{I}_{\mathrm{Na}, \mathrm{cAMP}}$ of the locomotor system is activated by serotonergic inputs, while Type 1 of the feeding network is thought to be regulated peptidergically. NO synthase activity is high in the CNS, where it differs from standard neuronal $\mathrm{NO}$ synthase in not being $\mathrm{Ca}^{2+}$ sensitive. $\mathrm{NO}$ acidifies $\mathrm{pH}_{\mathrm{i}}$, potentiating Type 1 , and may act to open proton channels. A cGMP pathway does not mediate NO effects as in other systems. Rather, nitrosylation likely mediates its actions. An integrated model of the action of cAMP, $\mathrm{Ca}^{2+}, \mathrm{pH}_{\mathrm{i}}$, and $\mathrm{NO}$ in the feeding network postulates that NO regulates proton conductance to cause neuronal excitation in the cell body on the one hand, and relief of activity-induced hyperacidification in fine dendritic processes on the other.
\end{abstract}

KEYWORDS: Command neuron, peptide, intracellular $p H, h$-current, nitric oxide

\section{INTRODUCTION}

The exploration of command neuron function in the nervous system of the predatory sea-slug Pleurobranchaea californica (Figure 1) initiated several decades of fascinating inquiry into chemical modulation of plasticity of a novel cation current. Like many good scientific inquiries, its course was marked by blind alleys, unrelated but important observations, and satisfying arrivals at truth. The experimental focus was an exploration of neurons on the ventral side of the animal's buccal ganglion, which controls the biting and swallowing movements of the feeding apparatus, the buccal mass. After sampling various neuron cell bodies with an intracellular microelectrode while simultaneously recording motor nerves with extracellular suction electrodes, the experimenter penetrated a neuron whose whitish albedo suggested a peptidergic nature. The neuron, later unimaginatively named the ventral white cell (VWC), put on a spectacular display of neurophysiological fireworks.

The neuron spontaneously initiated a depolarizing plateau potential with a rapid burst of action potentials lasting tens of seconds, and even over a minute (Figure 2). ${ }^{1}$ The bursts were endogenously generated; and spontaneous, slow plateau

Special Issue: Model Systems in Neuroscience

Received: April 19, 2018

Accepted: August 1, 2018

Published: August 1, 2018 


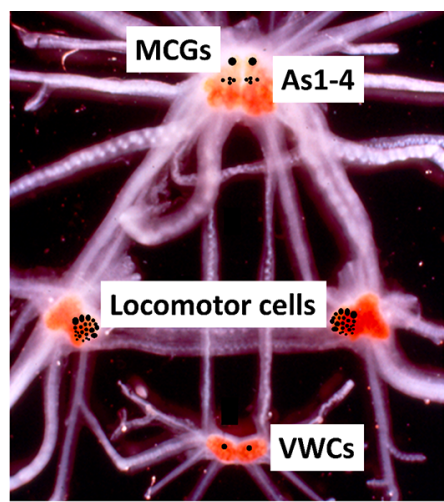

Figure 1. Pleurobranchaea's nervous system, showing cells of interest here: the cell bodies of the serotonergic metacerebral giant neurons (MCGs) and the As1-4 neurons lie in the cerebral lobes of the cerebropleural ganglion, those of the serotonergic cilio-locomotor neurons in the pedal ganglia, and the VWCs in the buccal ganglia.

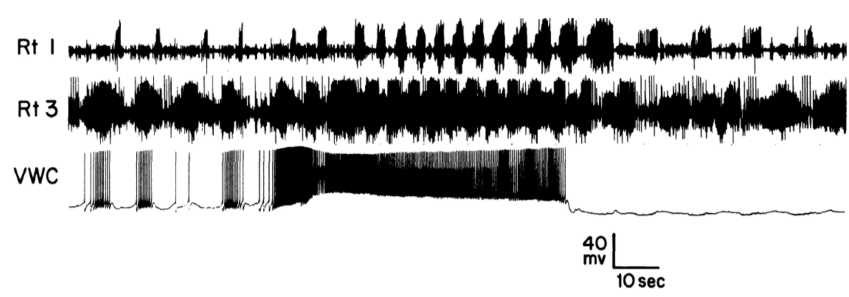

Figure 2. Spontaneous feeding activity recorded from an isolated buccal ganglion preparation illustrating the two types of burst activity typically seen in VWC. Upper two records are extracellular recordings from motor nerve roots 1 and 3 of the buccal ganglion, while lower record is an intracellular recording from the ipsilateral VWC. Typical transition from short bursts phase-locked to feeding to longer burst accompanied by intensified feeding activity is illustrated. Bursts in Rts 1 and 3 occur during fictive radular protraction and retraction, respectively. Modified from ref 7 .

potentials could be observed in isolated VWC somata. Prolonged bursts could be stimulated by brief excitation with depolarizing current from the microelectrode, with activity that far outlasted the triggering stimulus (Figure 3). Moreover, as the action potentials repeated, they progressively broadened from an initial duration at half a mplitude of $\sim 10 \mathrm{~ms}$ to durations over $200 \mathrm{~ms}$ in some experiments (Figure 4). Most remarkable was that as the neuron fired, the central pattern generator of the feeding rhythm embodied in the buccal ganglion initiated markedly high frequency bursts of rhythmic feeding motor output recorded in the nerves (Figures 2 and 5). A triad of exciting problems had just emerged in a single experiment: (1) A new command neuron had identified itself at a time when the natures and functional roles of command neurons were subjects of hot debate, ${ }^{2}$ and few such neurons were available for study at the cellular level. (2) How did the neuron sustain its prolonged plateau activity and firing? (3) What was the mechanism and functional significance of the extreme progressive spike broadening?

\section{THE COMMAND ROLE OF THE VWC}

Low-level and spontaneous cyclic feeding network activity is often recordable from the buccal motor nerve roots, and the VWC tends to fire slow packets of spikes in phase with bursts of retraction motorneurons (Figure 2). The command role of the VWC in the isolated buccal ganglion manifests in

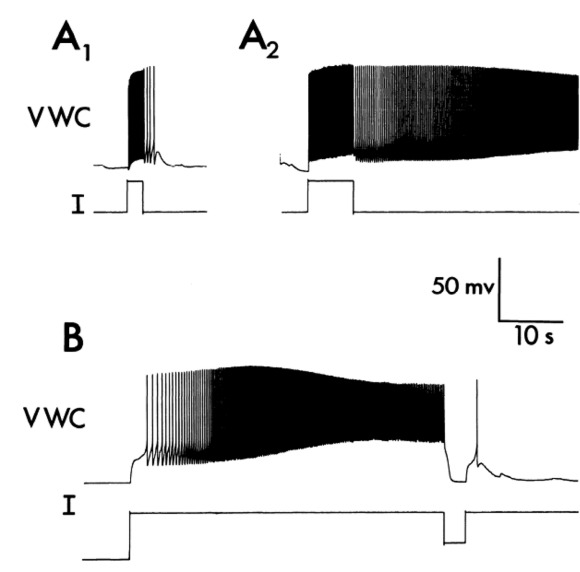

Figure 3. Initiation and suppression of prolonged VWC bursts by current injection. (A1) A short injection of depolarizing current initiates spikes and is followed by a depolarizing afterpotential, which supports several further spikes. (A2) A longer current phase triggers a full prolonged burst. (B) A burst is initiated on rebound from imposed hyperpolarization and is terminated by a short hyperpolarizing pulse. Evidence that the current pulse terminates the burst is the lack of a characteristic slow repolarization during which spikes regain amplitude, as seen in the latter portion of the burst shown in Figure 2. Modified from ref 7.

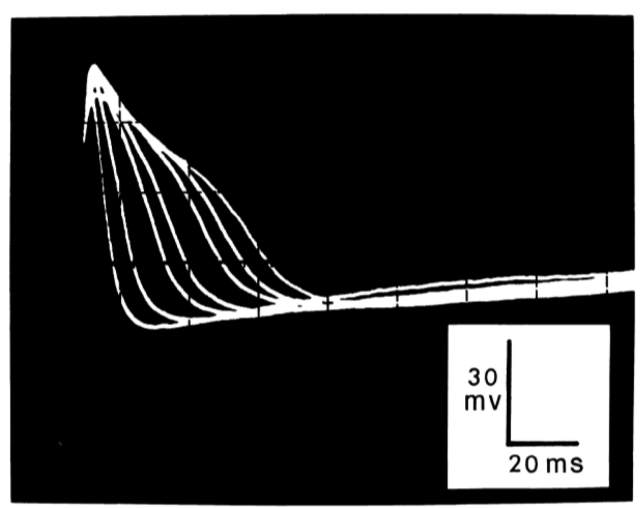

Figure 4. Superimposed action potentials from a depolarizationinduced train showing progressive spike broadening. Action potentials were driven at about $3 \mathrm{~Hz}$ by a separate current-passing electrode and samples, respectively, at $0,10,20,30,45,60$, and 90 s. Thus, the first and approximately 30 th, 60th, 90th, 135th, 180th, and 270th spikes of the train are shown. From ref 7 .

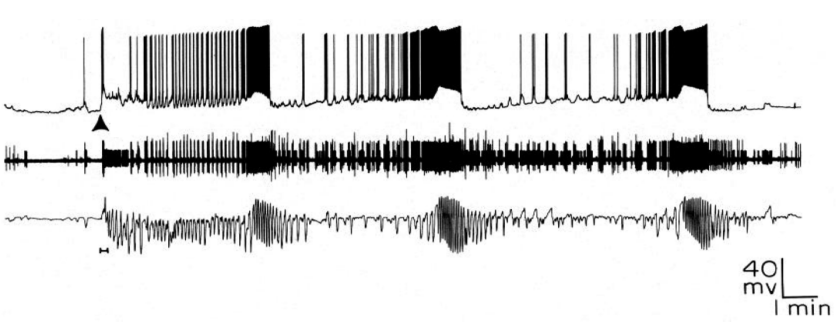

Figure 5. Consummatory buccal mass movements during VWC activity in a semi-intact preparation. Shown are responses of the VWC (intracellular record), contralateral stomagastric (gastroesophageal) nerve (extracellular record), and buccal mass (BM) (force transducer record). Records are continuous. Squid homogenate was introduced directly into the buccal cavity via cannula (arrowhead). Downward deflections of the trace mark protraction. Modified from ref 3. 
prolonged bursts of spikes that may trigger spontaneously (Figure 2) or are induced by short pulses of injected depolarizing current (Figure 3). During repetitive activity, the action potentials progressively broaden with spike repetition (Figure 4). The spike broadening was critical to the emergence of command ability. The motor output of the feeding network was induced at a threshold when VWC spikes had broadened to a half-amplitude duration of $20 \mathrm{~ms}$, a value that was consistent across preparations (avg 20.07, SEM 0.66, $N=3) .{ }^{1}$ We hypothesize that $20 \mathrm{~ms}$ might be the spike duration threshold at which the VWC releases a peptide to command the feeding motor output of the buccal ganglion.

\section{FUNCTIONAL SIGNIFICANCE}

The final cap on the functional significance came from studies in a semi-intact preparation retaining the CNS, the buccal mass feeding apparatus, and the chemosensory oral veil. ${ }^{3}$ In this preparation, it was painstakingly shown that the VWC was activated into prolonged burst/command mode by an appetitive stimulus of squid homogenate pipeted onto the oral veil, driving rhythmic feeding movements of the buccal mass (Figure 5). When an emetic stimulus (10\% ethanol in seawater) was applied, the VWC was hyperpolarized, although the feeding network drove cyclic rejection motor activity in buccal mass and nerves. ${ }^{4,5}$ Therefore, the VWC was concluded to act specifically as an ingestive feeding command neuron.

The VWC's command role was to accelerate the feeding motor network into a high frequency mode. ${ }^{1}$ At the same time, output of the VWC's axon innervating the crop/esophagus caused that structure to relax its circular muscle and shorten the longitudinal. This facilitated (1) eating as fast as possible and (2) stuffing the gut from the rear forward, efficiently in accord with the animal's ability to eat half its weight in one sitting! ${ }^{6}$

\section{PROGRESSIVE SPIKE BROADENING}

Investigations of progressive spike showed that the mechanism corresponded to one previously described for molluscan neurons without intrinsic bursting abilities. ${ }^{7}$ With the depolarization of the repetitive spiking, there was an accumulating slow inactivation of the delayed rectifier $\mathrm{K}^{+}$ current that repolarized the action potentials, which unmasked a $\mathrm{Ca}^{2+}$ current that formed a shoulder on the falling spike. Presumably, this enhanced $\mathrm{Ca}^{2+}$ influx led to the threshold of the neuron's ability to drive the feeding CPG, perhaps through release of its peptide(s).

\section{ROLE OF CAMP}

At the time, not long after the description of cAMP as a potent second messenger, it was being shown to modulate electrical neuron activity in molluscan neurons. ${ }^{8}$ Membrane permeant cAMP and the CAMP-phosphodiesterase inhibitor IBMX were tested on the VWC, and it was found that they induced the prolonged bursting activity. ${ }^{9}$ This observation started a search for its mechanism of action. We first went down one blind alley when current clamp observations seemed to tell us that cAMP caused a reduction in the $\mathrm{Ca}^{2+}$-activated, outward $\mathrm{K}^{+}$current. We needed to be able to measure effects on inward vs inward currents directly. R. Gillette built a voltage clamp to test the hypothesis, with help from John Connor. We trained ourselves, got the experiment to work, and were surprised to find that the salient effect of cAMP was to induce an inward cation current largely carried by $\mathrm{Na}^{+}{ }^{10}$ That was the last time we felt bad about being wrong about anything without strong proof. This current had been previously described (Liberman, Minina, and Golubtsov 1975), but not widely recognized. The characteristics of the current suggested that it was a species allied with the h-current of mammalian neurons and heart cells, a hyperpolarization-activated current requiring binding of cAMP. ${ }^{11}$ However, the character of the current in molluscan neurons varied in different neurons such that activation by hyperpolarization was not a ubiquitous defining characteristic.

The cAMP-activated cation current was now labeled $\mathrm{I}_{\mathrm{Na}, \mathrm{CAMP}}$, and was pursued at the single channel level. D. J. Green built the lab's first patch clamp and found that single $\mathrm{I}_{\mathrm{Na}, \mathrm{CAMP}}$ channels were remarkably easy to find and record on the VWC soma (Figure 6)..$^{10}$

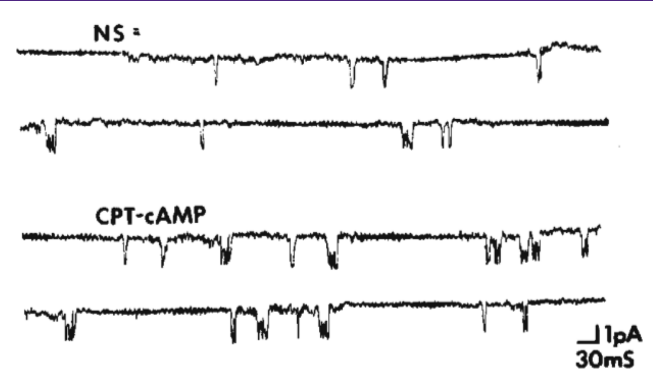

Figure 6. Effects of para-chlorophenylthio-cAMP (CPT cAMP) on single channel activity in a patch on an intact VWC neuron. CPT cAMP in the bath saline increased single channel activity while the cell is voltage clamped at $-50 \mathrm{mV}$. Upper two traces are continuous baseline recordings of single channel activity in normal saline (NS). Lower two traces are continuous recordings $10 \mathrm{~min}$ after bath addition of $10^{-4}$ M CPT-cAMP. Modified from ref 10 .

\section{TWO TYPES OF $\mathrm{I}_{\mathrm{Na}, \mathrm{CAMP}}$}

The current was characterized in neurons of the feeding network and later in serotonergic elements of the locomotor network in the pedal ganglia. We began precisely quantitating cAMP activation of $\mathrm{I}_{\mathrm{Na}, \mathrm{cAMP}}$ by iontophoretic injection. There were at least two types of $\mathrm{I}_{\mathrm{Na}, \mathrm{cAMP}}$, based on their voltage dependencies (Figure 7) and sensitivities to $\mathrm{pH}_{\mathrm{i}}$ and $\mathrm{Ca}^{2+}$. For the Type 1 voltage dependence, the current increased from -80 to $-30 \mathrm{mV}$, while the Type 2 current increased with hyperpolarization in that range, as for classic h-current. For both types extracellular $\mathrm{Ca}^{2+}$ acted like a depolarizationsensitive partial blocker, and its removal flattened out the voltage dependencies. ${ }^{12,13}$ The $I-V$ curve for the Type 1 current was suggestive that voltage sensitive $\mathrm{Ca}^{2+}$ entry could have an activating function. The Type 1 current also showed some $\mathrm{Ca}^{2+}$-sensitive inactivation after long depolarizations, which was an apparent mechanism for terminating the minutelong bursts in the VWC. ${ }^{14}$ The inactivation mechanism(s) may involve second messenger pathways. The Type 2 current was found in the serotonergic neurons of the locomotor effector neurons of the pedal ganglia. Type 2 was highly sensitive to inactivation with depolarization-induced $\mathrm{Ca}^{2+}$ influx, which was the major cause of its voltage sensitivity. ${ }^{13}$ Moreover, unlike the Type 1 current, the Type 2 current was insensitive to manipulations of $\mathrm{pH}_{\mathrm{i}} \cdot{ }^{14}$ The Type 1 current was also found in neurons of the serotonergic arousal network, ${ }^{15,16}$ including the metacerebral giant cell. ${ }^{17}$ 

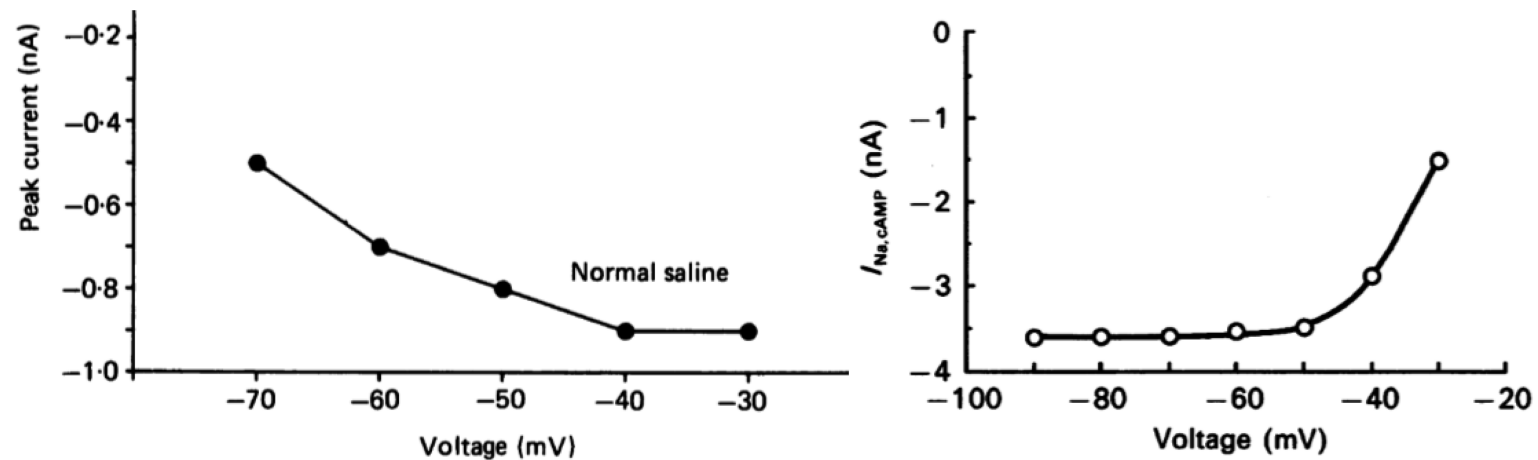

Figure 7. Voltage sensitivities of Type 1 (left) and Type 2 (right) $\mathrm{I}_{\mathrm{Na}, \mathrm{cAMP}}$ amplitude in normal saline in response to $5 \mathrm{~s}$ iontophoretic injections of cAMP. For Type 1, the current is increased by depolarization up to $-30 \mathrm{mV}$ (modified from ref 12). For Type 2, amplitude increases with more negative potentials from -30 to $-50 \mathrm{mV}$, and is stable at more hyperpolarized potentials like classical h-current (modified from ref 13 ). The currents both reverse near $0 \mathrm{mV}$ (not shown).

\section{CAMP GATING}

It was finally shown by L. Sudlow that stimulation of both types of $\mathrm{I}_{\mathrm{Na}, \mathrm{cAMP}}$ by cAMP was not blocked by intracellular injection of specific inhibitors of protein kinase A. ${ }^{18}$ Inward single-channel currents were activated in excised inside-out patches during exposure to cAMP in salines without added ATP. Sodium was the major current carrying ion. Two distinct types of $\mathrm{I}_{\mathrm{Na}, \mathrm{cAMP}}$ channel activity were observed, where opening probability and open times differed, but conductance was similar, $36.7 \mathrm{pS} .{ }^{18}$ These observations indicated that $\mathrm{I}_{\mathrm{Na}, \mathrm{cAMP}}$ activation occurs by direct binding of cAMP to a regulatory site at the channel, rather than by phosphorylation.

\section{MODELING AND MEASURING CAMP ACTIONS}

R.-C. Huang modeled cAMP diffusion kinetics in the neuron. ${ }^{19}$ This enabled L. Sudlow to develop novel theory with voltage clamp technique to use Type $2 \mathrm{I}_{\mathrm{Na}, \mathrm{cAMP}}$ to report on basal levels of endogenous cAMP and adenylyl cyclase, and on their stimulation by serotonin. ${ }^{20,21}$ Measurements were calibrated to iontophoretic cAMP injection currents to enable expression of the data in exact molar terms. In 30 neurons, serotonin stimulated on average a 23 -fold increase in submembrane [cAMP], effected largely by an 18-fold increase in adenylyl cyclase activity. Serotonin stimulation of adenylyl cyclase and [cAMP] was inversely proportional to cells' resting adenylyl cyclase activity. Average cAMP concentration at the membrane rose from 3.6 to $27.6 \mathrm{mM}$, levels consistent with the expected cAMP dissociation constants of the $\mathrm{I}_{\mathrm{Na}, \mathrm{cAMP}}$ channels. ${ }^{21}$ These measures confirmed the functional character of $\mathrm{I}_{\mathrm{Na}, \mathrm{cAMP}}$ in the context of high levels of native cAMP.

\section{INTRACELLULAR pH}

The $\mathrm{pH}_{\mathrm{i}}$ dependence of Type $1 \mathrm{I}_{\mathrm{Na}, \mathrm{cAMP}}$ was markedly interesting and quite enigmatic. It had been briefly described in Helix neurons. ${ }^{22}$ At the time, we wrongly assumed that cAMP would be acting through a phosphorylation mechanism. We virtually ignored recent findings of cyclic nucleotide-gated cation channels in retina and olfactory epithelium. Taking the bit in our teeth, we undertook a survey of $\mathrm{pH}$-sensitive phosphorylation in proteins separated on 1- and 2-D gels. ${ }^{23}$ The findings were interesting: of around 200 separable phosphoproteins, only a single one's phosphorylation state was quite sensitive to incubation of ganglion homogenate over a physiological $\mathrm{pH}$ range of 7.0-7.4. This protein was also identifiable in homogenates from lobster, sea urchin, and earthworm. The neutral isoelectric point, molecular weight, and triple phosphorylation suggested that it could be the eukaryotic elongation factor 2 (eEF-2), which is responsible for transferring the growing polypeptide chain from one ribosomal site to another as a new amino acid is loaded. This protein is the active target of diptheria toxin, and its phosphorylation suppresses protein synthesis.

The unique finding of $\mathrm{pH}$ sensitivity in the phosphorylation state seemed important, but we found it hard to publish, perhaps partly because the $\mathrm{pH}_{\mathrm{i}}$ sensitivity seemed a bit too exotic in the cell biology and biochemistry journals to which we submitted it. When it finally came out, ${ }^{23}$ we had already learned that the $\mathrm{I}_{\mathrm{Na} \text {,Camp }}$ channels were activated by direct cAMP ligand gating, and we did not wish to put more effort into the phosphorylation work, however significant it seemed at the time. Fortunately, Alexey Ryazanov learned of our work and his laboratory then found that the phosphorylating kinase, eEF-3 kinase, was exquisitely sensitive to both $\mathrm{Ca}^{2+}$-calmodulin and $\mathrm{pH}^{24}$ The ramifications of this dual sensitivity in the physiology of cells are slowly emerging.

Still, what was the significance of the $\mathrm{pH}_{\mathrm{i}}$ sensitivity of the Type $1 \mathrm{I}_{\mathrm{Na}, \mathrm{cAMP}}$ ? The answer lay in the unusual physiology of nitric oxide, the gaseous neurotransmitter, in Pleurobranchaea's nervous system.

NO synthase was found to be widely spread in the CNS, and the enzyme's activity was as high as in mammalian cortical tissue. $^{25-29}$ Moreover, unlike the NO synthases characterized in other molluscs, in Pleurobranchaea, it was insensitive to $\mathrm{Ca}^{2+}$, not resembling the neuronal and epithelial NO synthases of vertebrates, but being more like the $\mathrm{Ca}^{2+}$-insensitive $\mathrm{NO}$ synthase of macrophages. ${ }^{28}$

Applying NO donors to the CNS stimulated strong fictive motor output in the feeding motor network. Subsequent observations showed that $\mathrm{NO}$ acted to strongly potentiate the Type 1 , but not the Type $2, \mathrm{I}_{\mathrm{Na}, \mathrm{cAMP}}{ }^{30} \mathrm{~N}$. Hatcher found that intracellular injection of MOPS $\mathrm{pH}$ buffer blocked the action of NO. This suggested that NO might act by acidifying $\mathrm{pH}_{\mathrm{i}}$. Further, in the same study it was curious to find that NO's action was not mediated by cGMP. Indeed, cGMP lacked all the actions for which it is noted in other molluscs and in many reports on vertebrate systems. Nor was the NO effect mediated by cAMP, as for instance through some phosphorylation mechanism. We expect that NO's action in this system is an effect of direct target nitrosylation. Activation of h-current by 
NO independently of cGMP has now also been noted in rat hypoglossal motorneurons. ${ }^{31}$

A predicted effect of $\mathrm{NO}$ acting on $\mathrm{pH}_{\mathrm{i}}$ was confirmed by $\mathrm{K}$. Potgieter and C. McCrohan. ${ }^{32}$ Injections of the fluorescent $\mathrm{pH}$ indicator BCECF into neurons expressing Type $1 \mathrm{I}_{\mathrm{Na}, \mathrm{cAMP}}$ showed definitively that NO caused an intracellular acidification, up to $0.3 \mathrm{pH}$ units, that markedly potentiated the current (Figure 8). Moreover, alkalinizing $\mathrm{pH}_{\mathrm{o}}$ changed the

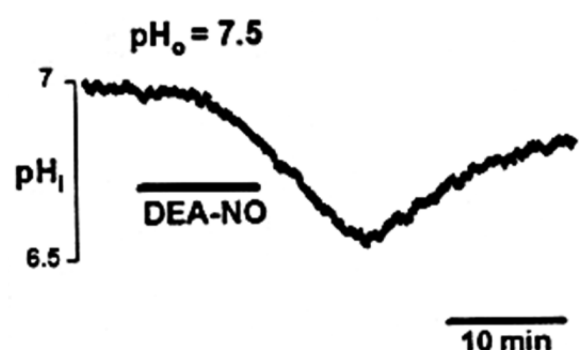

Figure 8. NO stimulates rapid intracellular $\mathrm{pH}$ change in an isolated soma of a metacerebral neuron. Bath application of the NO donor DEA-NO ( $1 \mathrm{mM}, 10 \mathrm{~min}$, solid bar) in saline at $\mathrm{pH} 7.5$ caused an acidification that peaked around $15 \mathrm{~min}$ after donor application and decayed slowly over minutes after washout. Resting potentials in these experiments were -45 to $-55 \mathrm{mV}$. Modified from ref 32 .

response of intracellular acidification to intracellular alkalinization, consistent with a mechanism where $\mathrm{NO}$ was opening membrane proton channels.

\section{PEPTIDERGIC NATURE OF THE VWC}

C. Lee and E. Romanova recently characterized the VWC peptides, a task made possible by creating a library of peptides in the nervous system. The library was created through a shotgun proteomics approach. ${ }^{33}$ Liquid chromatography mass spectrometry (LC-MS/MS) was used to determine putative peptide sequences, which were assigned based on a transcriptome of the Pleurobranchaea CNS (published under bioproject PRJNA329516 by the Katz group at Georgia State University). ${ }^{34}$ Resulting matches were assigned to respective prohormones, and the prohormones were searched for sequence homology using BLAST (https://blast.ncbi.nlm.nih. gov/Blast.cgi?PAGE=Proteins) against the NCBI molluscan protein database to determine homology with known prohormones from other species. Next we performed single cell matrix assisted laser desorption/ionization mass spectrometry $^{35,36}$ of isolated VWCs to determine their peptide content.

Using these single cell spectra, we observed that the VWC contains a number of putative peptides, of which a subset has been mass matched to characterized peptides in our Pleurobranchaea peptide library described above (Figure 9 and Table S1). By peptide mass fingerprint approach, we assign these matched peptides to two protein sequences supported by the transcriptome project PRJNA329516. Examination of the protein sequences for the presence of signal peptide and convention cleavage sited for endopeptidases allowed us to classify them as novel Pleurobranchaea prohormones: a FMRFamide producing prohormone, and another one homologous to Aplysia pedal peptide 4 (accession NP_001191626.1),

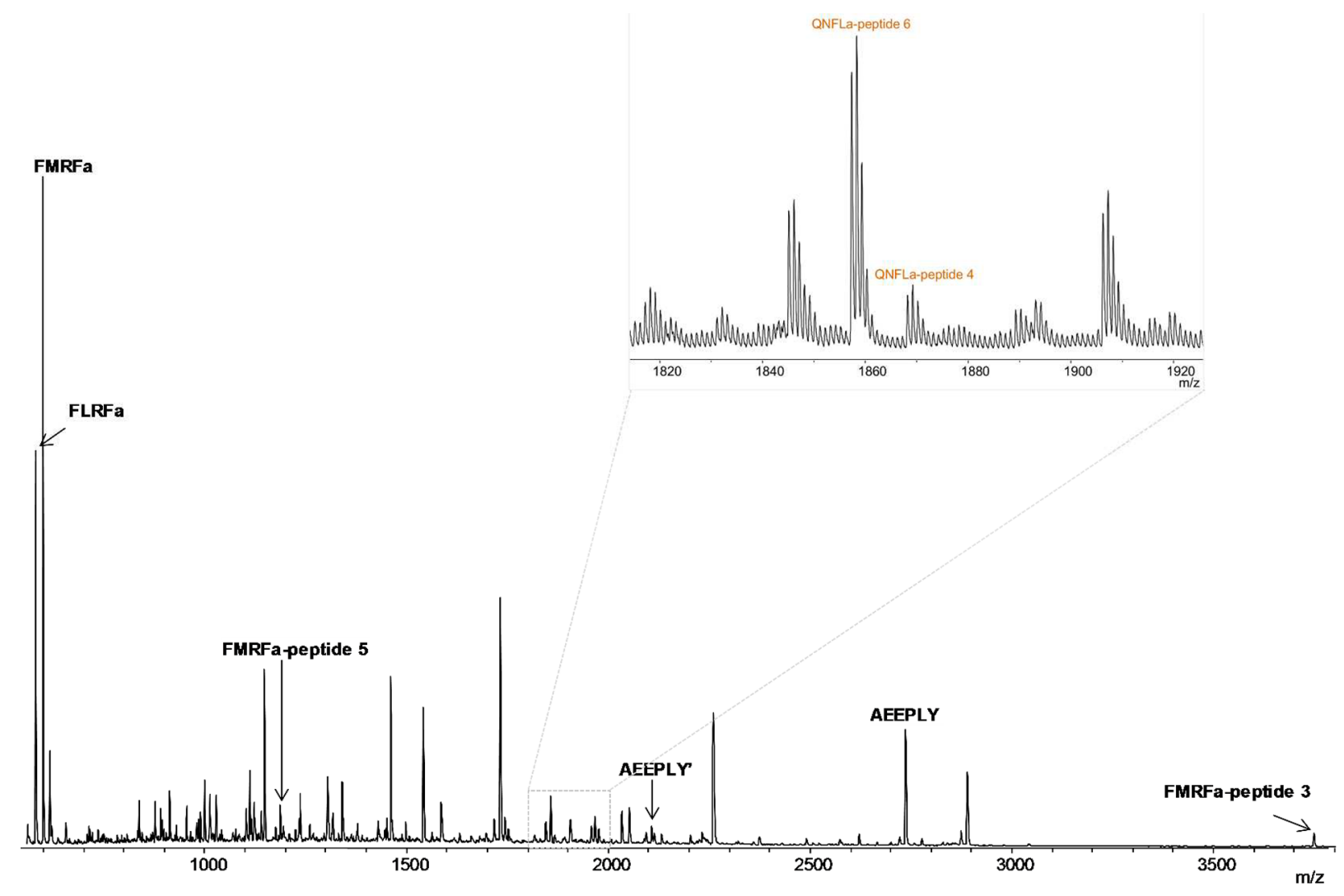

Figure 9. Representative MALDI-TOF MS spectrum from the buccal ganglion ventral white cell. We have identified peptides from two novel Pleurobranchaea prohormones in this neuron: a FMRFamide producing prohormone and a prohormone homologous to the Aplysia pedal peptide 4, which we have named QNFLa-peptides producing prohormone. Prohormone and peptide characterization metrics are presented in Table S1. 
which we have named QNFLa-peptides producing prohormone (Figure 9 and Table S1). Masses corresponding to predicted mass of $\mathrm{SCP}_{\mathrm{B}}$ were not detected, which is inconsistent with a homology with a bilateral pair of large $\mathrm{SCP}_{\mathrm{B}}$-staining cells in the buccal ganglia of a number of nudibranchs that were also shown to produce feeding motor output when driven. ${ }^{37} \mathrm{~A}$ difference is that the nudibranch neurons project ipsilaterally out the gastroesophageal nerve and the Pleurobranchaea VWCs project to the nerve contralaterally. While exact functions of these peptides remain unexplored at this time, they may enable the VWC to affect multiple aspects of feeding. The VWC provides a motive force to feeding interneurons that initiate feeding, but also projects to the esophagus to cause longitudinal contraction and radial relaxation during feeding. These physiological actions are correlated but not identical, and thus the use of different neuropeptides might be relevant to the simultaneous control of these two coordinated behaviors. Coexpressed peptides often have different rates of synthesis, and different release sites and kinetics, ${ }^{38}$ which enable a single neuron to exert multiple effects.

\section{NEUROTRANSMITTER ACTIVATION OF $I_{\text {Na, AMP }}$}

Type $2 \mathrm{I}_{\mathrm{Na}, \mathrm{cAMP}}$ of the locomotor neurons is activated by serotonin, the natural source of which is likely the As neurons of the cerebral lobe, ${ }^{15}$ thought to command cilio-locomotion. The transmitters/modulators that naturally induce bursting via Type $1 \mathrm{I}_{\mathrm{Na}, \mathrm{cAmP}}$ in the VWC are expected to be peptides, ${ }^{39}$ none of which have been yet tested. Analysis of the peptide complement of the VWC has tentatively identified peptides from two novel prohormones (Figure 9 and Table S1). Some of these might act on the other neurons of the feeding network to mediate the VWC's command role. Indeed, it is possible that they will act on the VWC itself in an automodulatory capacity to induce its own bursting mode. In this scenario, depolarization of the VWC via synaptic input or injected current would release peptide(s) that would act back on the cell to stimulate cAMP synthesis and thereby activate $\mathrm{I}_{\mathrm{Na}, \mathrm{cAMP}}$. This remains to be tested.

Application of sequencing technologies to sea slug nervous systems markedly enlarges potential for identifying neuron homologies and peptide signaling. The Moroz laboratory applied sequencing technologies, including single-neuron transcriptome profiling, to CNS's of Aplysia ${ }^{36}$ and Pleurobranchaea and Tritonia (in preparation). Senatore et al. have sequenced CNS transcriptomes Tritonia diomedia ${ }^{34}$ and fellow Nudipleura Melibe leonina, Dendronotus iris, Flabellina iodinea, Hermissenda crassicornis, and Pleurobranchaea californica (in preparation). Tamvacakis et al. identified genes related to learning and memory in the CNS transcriptome of Hermissenda crassicornis. ${ }^{40}$ Cook et al. ${ }^{41}$ fingered sequences of circadian clock proteins Hermissenda crassicornis, Melibe leonina, and Tritonia diomedea. Such results enable identification of genes encoding cyclic nucleotide-gated channels, proton channels, NOS, components of the cyclic AMP and cGMP cascades, a diversity of putative $5 \mathrm{HT}$ receptors, and many neuropeptides. It should be possible to localize expression of these in each neuron of the feeding and locomotory circuits, comparing rest states and behavioral arousal. In many ways, NOS systems in Pleurobranchaea are quite distinct from those described in Aplysia and Clione (see further), perhaps reflecting a role of feeding ecology in evolution of NO signaling, molluscan feeding, and defensive behaviors. $^{29,30,42}$

\section{SIGNIFICANCE OF NO-INDUCED $\mathrm{pH}_{\mathrm{i}}$ ACIDIFICATION AND POTENTIATION OF TYPE 1 \\ $\mathrm{I}_{\mathrm{Na}, \mathrm{cAMP}}$}

The activation of bursting activity in the VWC and the rest of the feeding network by Type $1 \mathrm{I}_{\mathrm{Na} \text {, cAMP }}$ also causes appreciable influx of $\mathrm{Ca}^{2+}$. Willoughby and Schwiening ${ }^{43,44}$ have elegantly shown that such $\mathrm{Ca}^{2+}$ influx is accompanied by marked proton production by $\mathrm{Ca}^{2+}$ buffering processes of extrusion and sequestration, which causes marked $\mathrm{pH}_{\mathrm{i}}$ acidification in fine dendritic processes to the extent that could locally compromise the cell's physiology. If $\mathrm{NO}$ does actually open $\mathrm{H}^{+}$channels, then dendritic proton channels would relieve the acidification by conducting protons outward under dual conditions of acidification and depolarization. A model for these actions is shown in Figure 10.

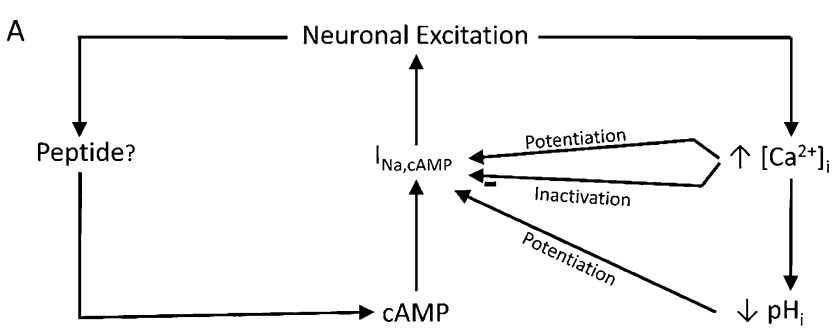

B

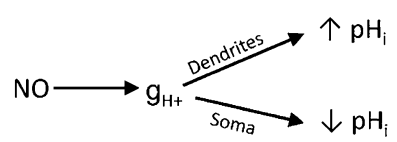

Figure 10. Integrated model for the actions of cAMP, $\mathrm{NO}$, and $\mathrm{pH}_{\mathrm{i}}$ in neurons of the feeding network. (A) Presumed peptidergic neuromodulators stimulate neuronal production of cAMP, which activates $\mathrm{I}_{\mathrm{Na}, \mathrm{AMM}}$. The resulting electrical activity is accompanied by $\mathrm{Ca}^{2+}$ influx and decrease in $\mathrm{pH}_{\mathrm{i}}$ due to proton production by $\mathrm{Ca}^{2+}$ buffering processes. Increased $\left[\mathrm{Ca}^{2+}\right]_{\mathrm{i}}$ has effects on $\mathrm{I}_{\mathrm{Na}, \mathrm{cAMP}}$ via different pathways: both a potentiation of the current causing Type $1 \mathrm{I}_{\mathrm{Na}, \mathrm{cAMP}}$ voltage dependence, and a slower inactivation of the current. (B) NO increases a proton conductance, $\mathrm{g}_{\mathrm{H}+}$. In the large neuron cell body proton entrance decreases $\mathrm{pH}_{\mathrm{i}}$, which will potentiate $\mathrm{I}_{\mathrm{Na}, \mathrm{cAMP}}$ and drive excitation. In the fine dendrites of the neuron, $\mathrm{Ca}^{2+}$ entry in activity may cause large acid transients, possibly harmful to the cell's physiology, and which would be relieved by the proton conductance to the outside.

These interesting effects still remain to be followed up. There are few studies of effects of $\mathrm{NO}$ on $\mathrm{pH}_{\mathrm{i}}$; but there are reports that NO donors caused marked intracellular acidification through unknown mechanisms in cultured cardiac cells ${ }^{45}$ and hippocampal neurons. ${ }^{46}$ Whether these results were independent of cGMP was not determined. There are fewer reports still on $\mathrm{pH}_{\mathrm{i}}$ regulation of cyclic nucleotide-activated cation currents. The Type $1 \mathrm{I}_{\mathrm{Na}, \mathrm{cAMP}}$ has not yet been investigated outside of Pleurobranchaea. These directions remain to be followed by some adventurous souls.

$\mathrm{I}_{\mathrm{Na}, \mathrm{cAMP}}$ is widely spread in molluscan nervous systems, and has been found in feeding network neurons of Lymnaea, ${ }^{47}$ Helix (Cornu) aspersa, ${ }^{22}$ Archidoris montereyensis and Aplysia californica, ${ }^{48}$ and Navanax (Green and Gillette, unpublished). It was of appreciable interest to find that the epileptogenic drug pentylenetetrazol markedly potentiated $\mathrm{I}_{\mathrm{Na}, \mathrm{cAMP}}$ in 
Lymnaea neurons as it simultaneously caused chaotic electrical activity, possibly in tandem with inhibition of native cAMP degradation. $^{49}$ In Pleurobranchaea, and likely the other gastropods, $\mathrm{I}_{\mathrm{Na}, \mathrm{cAMP}}$ provides the major "psychic energy" that underlies feeding, locomotion, and the serotonergic arousal network. The multiple roles and regulation of this h-type current merit further investigation.

\section{ASSOCIATED CONTENT}

\section{S Supporting Information}

The Supporting Information is available free of charge on the ACS Publications website at DOI: 10.1021/acschemneuro.8b00187.

Pleurobranchaea prohormone peptide library and metrics (XLSX)

\section{AUTHOR INFORMATION}

\section{Corresponding Author}

*E-mail: rhanor@illinois.edu.

\section{ORCID}

Elena V. Romanova: 0000-0002-2040-3312

Jonathan V. Sweedler: 0000-0003-3107-9922

Martha L. U. Gillette: 0000-0003-3645-2626

Rhanor Gillette: 0000-0001-7428-6214

\section{Present Addresses}

${ }^{\#}$ D.G.: Medical Eye Services, 48 S. Greenleaf Avenue, Gurnee, IL 60031.

${ }^{\nabla}$ R.-C.H.: Chang Gung College of Medicine and Technology Taiwan, R.O.C.

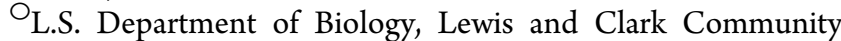
College, Godfrey, IL 62035.

N.H. Neuroscience, Merck Research Laboratories, West Point, PA 19486.

${ }^{\text {II }}$ K.P.: Oakwood Animal Hospital, 4132 McEver Road, Oakwood, GA 30566.

\section{Funding}

This work was partially supported by Award No. P30 DA018310 from the National Institute on Drug Abuse (C.L., E.V.R., and J.V.S.).

Notes

The authors declare no competing financial interest.

\section{REFERENCES}

(1) Gillette, R., Gillette, M. U., and Davis, W. J. (1980) Actionpotential broadening and endogenously sustained bursting are substrates of command ability in a feeding neuron of Pleurobranchaea. J. Neurophysiol. 43, 669-685.

(2) Kupfermann, I., and Weiss, K. R. (1978) The command neuron concept. Behavioral and Brain Sciences 1, 3.

(3) Gillette, M. U., and Gillette, R. (1983) Bursting neurons command consummatory feeding behavior and coordinated visceral receptivity in the predatory mollusk Pleurobranchaea. J. Neurosci. 3, $1791-1806$

(4) Croll, R. P., Davis, W. J., and Kovac, M. P. (1985) Neural mechanisms of motor program switching in the mollusc Pleurobranchaea. I. Central motor programs underlying ingestion, egestion, and the "neutral" rhythm(s). J. Neurosci. 5, 48-55.

(5) Croll, R. P., Davis, W. J., and Kovac, M. P. (1985) Neural mechanisms of motor program switching in the mollusc Pleurobranchaea. I. Central motor programs underlying ingestion, egestion, and the "neutral" rhythm(s). J. Neurosci. 5, 48-55.

(6) Gillette, M. U., and Gillette, R. (1983) Bursting neurons command consummatory feeding behavior and coordinated visceral receptivity in the predatory mollusk Pleurobranchaea. J. Neurosci. 3, $1791-1806$

(7) Gillette, R., Gillette, M. U., and Davis, W. J. (1982) Substrates of command ability in a buccal neuron of Pleurobranchaea. J. Comp. Physiol., A 146, 449-459.

(8) Treistman, S. N., and Levitan, I. B. (1976) Alteration of electrical activity in molluscan neurones by cyclic nucleotides and peptide factors. Nature 261, 62-64.

(9) Gillette, R., Gillette, M. U., and Davis, W. J. (1982) Substrates of command ability in a buccal neuron of Pleurobranchaea. J. Comp. Physiol., A 146, 461-470.

(10) Green, D. J., and Gillette, R. (1983) Patch- and voltage-clamp analysis of cyclic AMP-stimulated inward current underlying neurone bursting. Nature 306, 784-785.

(11) Luthi, A., and McCormick, D. A. (1998) H-current: Properties of a neuronal and network pacemaker. Neuron 21, 9-12.

(12) Gillette, R., and Green, D. J. (1987) Calcium dependence of voltage sensitivity in adenosine $3^{\prime}, 5^{\prime}$-cyclic phosphate-stimulated sodium current in Pleurobranchaea. J. Physiol. 393, 233-245.

(13) Huang, R. C., and Gillette, R. (1993) Co-regulation of cAMPactivated $\mathrm{Na}+$ current by $\mathrm{Ca} 2+$ in neurones of the mollusc Pleurobranchaea. J. Physiol. 462, 307-320.

(14) Green, D. J., and Gillette, R. (1988) Regulation of cAMPstimulated ion current by intracellular $\mathrm{pH}, \mathrm{Ca} 2+$, and calmodulin blockers. J. Neurophysiol. 59, 248-258.

(15) Jing, J., and Gillette, R. (1999) Central pattern generator for escape swimming in the Notaspid sea slug Pleurobranchaea californica. J. Neurophysiol. 81, 654-667.

(16) Gillette, R. (2006) Evolution and Function in Serotonergic Systems. Integr. Comp. Biol. 46, 838-846.

(17) Hatcher, N. G. (2006) Nitric Oxide Potentiates cAMP-Gated Cation Current in Feeding Neurons of Pleurobranchaea californica Independent of cAMP and cGMP Signaling Pathways. J. Neurophysiol. 95, 3219-3227.

(18) Sudlow, L. C., Huang, R. C., Green, D. J., and Gillette, R. (1993) cAMP-activated $\mathrm{Na}+$ current of molluscan neurons is resistant to kinase inhibitors and is gated by cAMP in the isolated patch. $J$. Neurosci. 13, 5188-5193.

(19) Huang, R. C., and Gillette, R. (1991) Kinetic analysis of cAMPactivated $\mathrm{Na}+$ current in the molluscan neuron. A diffusion-reaction model. J. Gen. Physiol. 98, 835-848.

(20) Sudlow, L. C., and Gillette, R. (1995) Cyclic AMP-gated sodium current in neurons of the pedal ganglion of Pleurobranchaea californica is activated by serotonin. J. Neurophysiol. 73, 2230-2236.

(21) Sudlow, L. C., and Gillette, R. (1997) Cyclic AMP levels, adenylyl cyclase activity, and their stimulation by serotonin quantified in intact neurons. J. Gen. Physiol. 110, 243-255.

(22) Aldenhoff, J. B., Hofmeier, G., Lux, H. D., and Swandulla, D. (1983) Stimulation of a sodium influx by cAMP in Helix neurons. Brain Res. 276, 289-296.

(23) Gillette, R., Gillette, M., Lipeski, L., and Connor, J. (1990) pHsensitive, $\mathrm{Ca} 2+/$ calmodulin-dependent phosphorylation of unique protein in molluscan nervous system. Biochim. Biophys. Acta, Gen. Subj. 1036, 207-212.

(24) Dorovkov, M. V., Pavur, K. S., Petrov, A. N., and Ryazanov, A. G. (2002) Regulation of elongation factor-2 kinase by $\mathrm{pH}$. Biochemistry 41, 13444-13450.

(25) Floyd, P. D., Moroz, L. L., Gillette, R., and Sweedler, J. V. (1998) Capillary electrophoresis analysis of nitric oxide synthase related metabolites in single identified neurons. Anal. Chem. 70, 2243-2247.

(26) Hurst, W. J., Moroz, L. L., Gillette, M. U., and Gillette, R. (1999) Nitric Oxide Synthase Imunolabeling in the Molluscan CNS and Peripheral Tissues. Biochem. Biophys. Res. Commun. 262, 545548.

(27) Moroz, L. L., and Gillette, R. (1996) NADPH-diaphorase localization in the CNS and peripheral tissues of the predatory seaslug Pleurobranchaea californica. J. Comp. Neurol. 367, 607-622. 
(28) Moroz, L. L., Chen, D., Gillette, M. U., and Gillette, R. (1996) Nitric oxide synthase activity in the molluscan CNS. J. Neurochem. 66, 873-876.

(29) Moroz, L. L., Norekian, T. P., Pirtle, T. J., Robertson, K. J., and Satterlie, R. A. (2000) Distribution of NADPH-diaphorase reactivity and effects of nitric oxide on feeding and locomotory circuitry in the pteropod mollusc, Clione limacina. J. Comp. Neurol. 427, 274-284.

(30) Hatcher, N. G., Sudlow, L. C., Moroz, L. L., and Gillette, R. (2006) Nitric oxide potentiates cAMP-gated cation current in feeding neurons of Pleurobranchaea californica independent of cAMP and cGMP signaling pathways. J. Neurophysiol. 95, 3219-3227.

(31) Wenker, I. C., Benoit, J. P., Chen, X., Liu, H., Horner, R. L., and Mulkey, D. K. (2012) Nitric oxide activates hypoglossal motoneurons by cGMP-dependent inhibition of TASK channels and cGMPindependent activation of HCN channels. J. Neurophysiol. 107, 14891499.

(32) Potgieter, K., Hatcher, N. G., Gillette, R., and McCrohan, C. R. (2010) Nitric Oxide Potentiates cAMP-Gated Cation Current by Intracellular Acidification in Feeding Neurons of Pleurobranchaea. J. Neurophysiol. 104, 742-745.

(33) Romanova, E. V., and Sweedler, J. V. (2015) Peptidomics for the discovery and characterization of neuropeptides and hormones. Trends Pharmacol. Sci. 36, 579-586.

(34) Senatore, A., Edirisinghe, N., and Katz, P. S. (2015) Deep mRNA sequencing of the Tritonia diomedea brain transcriptome provides access to gene homologues for neuronal excitability, synaptic transmission and peptidergic signalling. PLoS One 10, e0118321.

(35) Zhang, G., Vilim, F. S., Liu, D. D., Romanova, E. V., Yu, K., Yuan, W. D., Xiao, H., Hummon, A. B., Chen, T. T., Alexeeva, V., Yin, S. Y., Chen, S. A., Cropper, E. C., Sweedler, J. V., Weiss, K. R., and Jing, J. (2017) Discovery of leucokinin-like neuropeptides that modulate a specific parameter of feeding motor programs in the molluscan model, Aplysia. J. Biol. Chem. 292, 18775-18789.

(36) Zhang, G., Yuan, W. D., Vilim, F. S., Romanova, E. V., Yu, K., Yin, S. Y., Le, Z. W., Xue, Y. Y., Chen, T. T., Chen, G. K., Chen, S. A., Cropper, E. C., Sweedler, J. V., Weiss, K. R., and Jing, J. (2018) Newly identified Aplysia SPTR-gene family-derived peptides: Localization and function. ACS Chem. Neurosci., DOI: 10.1021/acschemneur$0.7 \mathrm{~b} 00513$.

(37) Watson, W. H., 3rd, and Willows, A. O. (1992) Evidence for homologous peptidergic neurons in the buccal ganglia of diverse nudibranch mollusks. J. Neurobiol. 23, 173-186.

(38) Nusbaum, M. P., Blitz, D. M., and Marder, E. (2017) Functional consequences of neuropeptide and small-molecule cotransmission. Nat. Rev. Neurosci. 18, 389-403.

(39) Abrams, T. W., Castellucci, V. F., Camardo, J. S., Kandel, E. R., and Lloyd, P. E. (1984) Two endogenous neuropeptides modulate the gill and siphon withdrawal reflex in Aplysia by presynaptic facilitation involving cAMP-dependent closure of a serotonin-sensitive potassium channel. Proc. Natl. Acad. Sci. U. S. A. 81, 7956-7960.

(40) Tamvacakis, A. N., Senatore, A., and Katz, P. S. (2015) Identification of genes related to learning and memory in the brain transcriptome of the mollusc, Hermissenda crassicornis. Learn. Mem. $22,617-621$.

(41) Cook, G. M., Gruen, A. E., Morris, J., Pankey, M. S., Senatore, A., Katz, P. S., Watson, W. H., 3rd, and Newcomb, J. M. (2018) Sequences of Circadian Clock Proteins in the Nudibranch Molluscs Hermissenda crassicornis, Melibe leonina, and Tritonia diomedea. Biol. Bull. 234, 207-218.

(42) Moroz, L. L., and Gillette, R. (1995) From polyplacophora to cephalopoda: Comparative analysis of nitric oxide signalling in mollusca. Acta Biol. Hung. 46, 169-182.

(43) Schwiening, C. J., and Willoughby, D. (2002) Depolarizationinduced $\mathrm{pH}$ microdomains and their relationship to calcium transients in isolated snail neurones. J. Physiol. 538, 371-382.

(44) Willoughby, D., and Schwiening, C. J. (2002) Electrically evoked dendritic $\mathrm{pH}$ transients in rat cerebellar Purkinje cells. J. Physiol. 544, 487-499.
(45) Pravdic, D., Vladic, N., Cavar, I., and Bosnjak, Z. J. (2012) Effect of nitric oxide donors S-nitroso-N-acetyl-DL-penicillamine, spermine NONOate and propylamine propylamine NONOate on intracellular $\mathrm{pH}$ in cardiomyocytes. Clin. Exp. Pharmacol. Physiol. 39, 772-778.

(46) Vincent, A. M., TenBroeke, M., and Maiese, K. (1999) Neuronal intracellular $\mathrm{pH}$ directly mediates nitric oxide-induced programmed cell death. J. Neurobiol. 40, 171-184.

(47) McCrohan, C. R., and Gillette, R. (1988) Cyclic AMPstimulated sodium current in identified feeding neurons of Lymnaea stagnalis. Brain Res. 438, 115-123.

(48) Connor, J. A., and Hockberger, P. (1984) A novel membrane sodium current induced by injection of cyclic nucleotides into gastropod neurones. J. Physiol. 354, 139-162.

(49) McCrohan, C. R., and Gillette, R. (1988) Enhancement of cyclic AMP-dependent sodium current by the convulsant drug pentylenetetrazol. Brain Res. 452, 21-27. 